\title{
The dilemma of whether to continue TNF $\alpha$ blocker therapy in an ulcerative colitis patient newly diagnosed with a malignant melanoma and melanoma in situ
}

\author{
Louise Zuzarte, ${ }^{1}$ Sara Mirhadi, ${ }^{1}$ Richard A Carr, ${ }^{2}$ Simon Tso (D) ${ }^{1}$
}

${ }^{1}$ Jephson Dermatology Center, South Warwickshire NHS Foundation Trust, Warwick, UK ${ }^{2}$ Department of Histopathology, South Warwickshire NHS Foundation Trust, Warwick, UK

\section{Correspondence to} Dr Simon Tso: simontso@doctors.org.uk

Accepted 26 October 2019

\section{DESCRIPTION}

Our case concerns a 75 -year-old Caucasian woman with Fitzpatrick type 1 skin who presented to our department with a $6 \mathrm{~mm}$ irregularly shaped pigmented lesion on her right upper back. Full skin examination revealed a $1 \mathrm{~cm}$ irregularly shaped melanocytic lesion on her left calf (figure 1). She has a history of ulcerative colitis (UC) managed with an adalimumab biosimilar 2 months prior to presentation; previous to this she had received adalimumab (Humira) for 4 months. Other treatments she has previously received for her UC included prednisolone and mesalazine only. The right upper back lesion was excised revealing a superficial spreading malignant melanoma (figure 2A,B; pT1b, Breslow thickness $0.8 \mathrm{~mm}$; Clark level III; clinical stage 1a). Subsequent $1 \mathrm{~cm}$ wide local excision revealed scar tissue only. The left calf lesion revealed melanoma in situ (figure 2C,D) excised with $5 \mathrm{~mm}$ radial margin.

Adalimumab is a fully human recombinant IgG1 monoclonal cytokine of the innate immune system that blocks tumour necrosis factor alpha (TNF $\alpha$ ), which in turn plays a key role in the surveillance of malignancies. Our manuscript reviewer helpfully highlighted the current literature reported different perspectives on the melanoma risks of patients on TNF $\alpha$ blockers: neutral, with or against the theory. There were case reports associating TNF $\alpha$ blockers with an increased risk of developing melanoma (Crohn's disease and adalimumab ${ }^{1}$; psoriasis and adalimumab) ${ }^{2}$ or recurrence of malignant melanoma (rheumatoid arthritis and adalimumab). ${ }^{3}$ Long et al reported a number of inflammatory bowel disease (IBD) patients on TNF $\alpha$ blockers

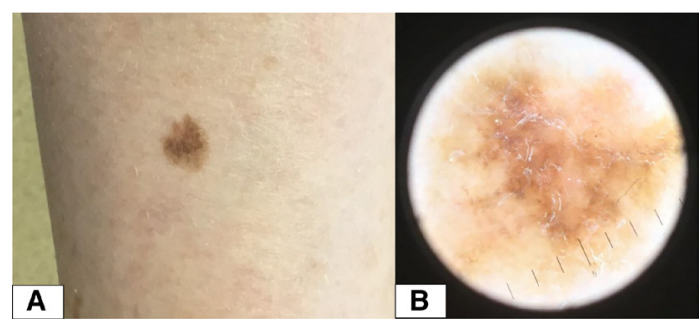

Figure 1 (A) An asymmetrical irregular-shaped variegated colour melanocytic lesion located on the patient's left calf. (B) The dermoscopy view of the asymmetrical melanocytic lesion with atypical networks and globules.

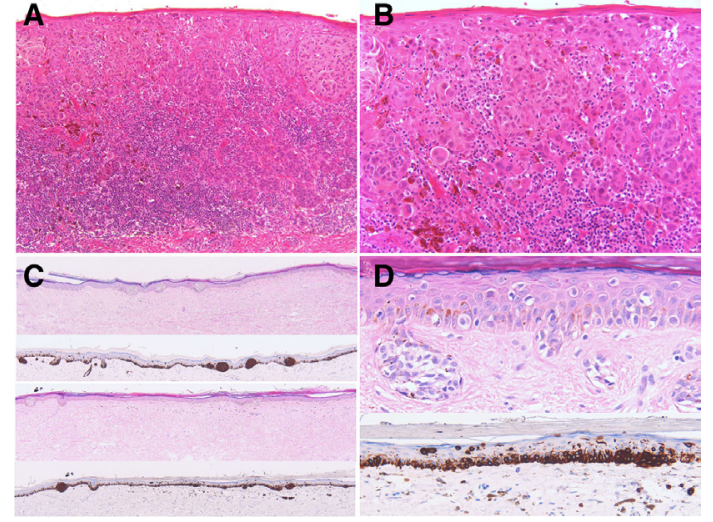

Figure 2 Lesion right mid back $(A, B)$ showing a superficial spreading malignant melanoma, vertical growth phase, Breslow $0.8 \mathrm{~mm}$ (H\&E 100x and H\&E $200 \times)$. Lesion left calf $(C, D)$ interpreted as a partly nested but widely lentiginous mildly atypical melanocytic proliferation with some pagetoid ascent favouring melanoma in situ (H\&E 50x and H\&E 40x). The irregularity of the junctional nesting and the extent of lentiginous and pagetoid spread are highlighted by the associated immunostaining panels (MelanA at 50x and 200x).

developed a melanoma. ${ }^{4}$ They postulated the potential mechanism for this could include melanomas developing in the condition of immunosuppression, or de novo lesions developing secondary to increasing photosensitivity. Conversely, a systematic review by Singh et al demonstrated an increased risk of melanoma in IBD patients independent of biological treatment, thereby encouraging clinicians to warn patients of this risk irrespective of their intended treatments. ${ }^{5}$ Therefore, highlighting the importance of long-term skin surveillance in this patient population. The patient was counselled about the association between TNF $\alpha$ blocker and melanoma risks including our findings from the literature as stated above. Guided by patient choice, and in conjunction with the gastroenterology and dermatology teams, she continued on adalimumab biosimilar treatment while undergoing long-term skin surveillance. We advocate that patient education when starting biologics, as well as in at risk groups such as IBD patients, through regular skin surveillance and reduced sun exposure may help to identify early melanomas. Continued long-term data acquisition through biological registries will 
also help to further appraise risks in such treatment groups. Treatment choices in patients with IBD and melanoma are challenging, and there are limited data available to help guide management. Treatment and follow-up should therefore be individualised, extensively discussed with patients and their families as appropriate, and done in conjunction with close follow-up by gastroenterologist and dermatologist.

\section{Learning points}

- The literature reported an association between melanoma and inflammatory bowel disease.

- The literature also reported an association between melanoma and tumour necrosis factor alpha blockers.

- Patient education when starting biologics, as well as in at risk groups such as inflammatory bowel disease patients, through regular skin surveillance and reduced sun exposure may help to identify early melanomas.

Acknowledgements The authors would like to thank Dr Rachel Browne, Dr Emily Forbat and Dr Bruce Gee for the valuable feedback on an initial draft of this manuscript.

Contributors ST was responsible for the initial conception and design of the manuscript, and critically revising it for its intellectual consent. LZ and SM cowrote the initial draft and made critical revisions to the manuscript. RAC was responsible writing the histopathology aspects of the manuscript. All authors have reviewed the final version of the manuscript and consented to the submission.

Funding The authors have not declared a specific grant for this research from any funding agency in the public, commercial or not-for-profit sectors.

Competing interests None declared.

Patient consent for publication Obtained.

Provenance and peer review Not commissioned; externally peer reviewed.

\section{ORCID iD}

Simon Tso http://orcid.org/0000-0001-9221-7618

\section{REFERENCES}

1 Kouklakis G, Efremidou El, Pitiakoudis M, et al. Development of primary malignant melanoma during treatment with a TNF- $\alpha$ antagonist for severe Crohn's disease: a case report and review of the hypothetical association between TNF- $\alpha$ blockers and cancer. Drug Des Devel Ther 2013;7:195-9.

2 Gordon KB, Langley RG, Leonardi C, et al. Clinical response to adalimumab treatment in patients with moderate to severe psoriasis: double-blind, randomized controlled trial and open-label extension study. J Am Acad Dermatol 2006;55:598-606.

3 Fulchiero GJ, Salvaggio H, Drabick JJ, et al. Eruptive latent metastatic melanomas after initiation of antitumor necrosis factor therapies. J Am Acad Dermatol 2007;56:S65-7.

4 Long MD, Martin CF, Pipkin CA, et al. Risk of melanoma and nonmelanoma skin cancer among patients with inflammatory bowel disease. Gastroenterology 2012;143:390-9.

5 Singh S, Nagpal SJS, Murad MH, et al. Inflammatory bowel disease is associated with an increased risk of melanoma: a systematic review and meta-analysis. Clin Gastroenterol Hepatol 2014;12:210-8.

Copyright 2019 BMJ Publishing Group. All rights reserved. For permission to reuse any of this content visit

https://www.bmj.com/company/products-services/rights-and-licensing/permissions/

BMJ Case Report Fellows may re-use this article for personal use and teaching without any further permission.

Become a Fellow of BMJ Case Reports today and you can:

- Submit as many cases as you like

- Enjoy fast sympathetic peer review and rapid publication of accepted articles

- Access all the published articles

- Re-use any of the published material for personal use and teaching without further permission

\section{Customer Service}

If you have any further queries about your subscription, please contact our customer services team on +44 (0) 2071111105 or via email at support@bmj.com.

Visit casereports.bmj.com for more articles like this and to become a Fellow 